\title{
PENGARUH KUALITAS PRODUK, KUALITAS LAYANAN DAN CITRA MEREK TERHADAP NIAT PEMBELIAN ULANG
}

\author{
I Dewa Gde Agung Ekaprana ${ }^{1}$ \\ I Made Jatra ${ }^{2}$ \\ I Gusti Ayu Ketut Giantari ${ }^{3}$ \\ ${ }^{1,2,3}$ Fakultas Ekonomi dan Bisnis Universitas Udayana (Unud), Bali, Indonesia \\ email: dwgdagungekaprana@yahoo.com
}

\begin{abstract}
ABSTRAK
Terjadinya fluktuasi penjualan sepeda motor pada Dealer Astra Motor Center Denpasar membuat Honda harus bekerja lebih keras untuk meningkatkan kembali jumlah penjualan produknya. Dengan niat pembelian ulang diharapkan dapat meningkatkan jumlah penjualan produknya. Tujuan penelitian ini adalah untuk menjelaskan pengaruh kualitas produk, kualitas layanan dan citra merek terhadap niat pembelian ulang pada Dealer Astra Motor Center Denpasar. Penelitian ini dilakukan di Dealer Astra Motor Center Denpasar, dengan jumlah responden sebanyak 126. Pengambilan sampel ini menggunakan metode purposive sampling. Teknik analisis yang digunakan adalah analisis regresi berganda dengan Statitical Package of Sosial Science (SPSS) 17.0. Hasil penelitian menunjukkan kualitas produk, kualitas pelayanan dan citra merek berpengaruh positif dan signifikan terhadap niat pembelian ulang sepeda motor merk Honda di Kota Denpasar.

Kata kunci : niat pembelian ulang; kualitas produk; kualitas layanan dan citra merek
\end{abstract}

\begin{abstract}
Fluctuations in motorcycle sales at Denpasar Astra Motor Center Dealers make Honda have to work harder to increase the number of sales of its products. With the intention of repurchasing is expected to increase the number of sales of its products. The purpose of this study was to determine the effect of product quality, service quality and brand image on repurchase intentions at the Astra Motor Center Denpasar Dealer. This research was conducted at the Astra Motor Center Denpasar Dealer, with 126 respondents. The sample was taken using purposive sampling. The analysis technique used is multiple regression analysis with Statitical Package of Social Science (SPSS) 17.0. The results showed of product quality, service quality and brand image has a positive and significant effect on the intention to repurchase Honda motorcycles in Denpasar.

Keywords: repurchase intention; product quality; service quality and brand image
\end{abstract}




\section{PENDAHULUAN}

Perkembangan teknologi yang semakin maju menyebabkan kebutuhan akan suatu produk transportasi semakin meningkat, salah satunya adalah produk sepeda motor. Menurut Asosiasi Industri Sepeda Motor Indonesia penjualan sepeda motor daerah Bali hingga bulan Februari 2019 dikuasai oleh sepeda motor Honda dengan jumlah 77,11 persen, Yamaha 19,31 persen, Kawasaki 01,96 persen, Suzuki 1,6 persen dan TVS 0,02 persen. Data ini menunjukan saat ini Honda masih menguasai hampir keseluruhan dari penjualan sepeda motor di Indonesia. Tabel 1 menampilkan jumlah penjualan sepeda motor merek Honda di Denpasar tahun 2014 - 2018.

\section{Tabel 1}

Jumlah Penjualan Sepeda Motor Merek Honda Di Kota Denpasar Tahun 2014 - 2018 (Unit).

\begin{tabular}{cccc}
\hline NO & Tahun & Jumlah Penjualan (Unit) & Perubahan (persen) \\
\hline 1 & 2014 & 82.338 & - \\
2 & 2015 & 74.765 & $(9,19)$ \\
3 & 2016 & 63.283 & $(15,35)$ \\
4 & 2017 & 55.694 & $(12)$ \\
5 & 2018 & 65.682 & 15,20 \\
\hline
\end{tabular}

Sumber: PT. Astra Honda Cokroaminoto, 2018

Tabel 1. menunjukkan jumlah penjualan sepeda motor merek Honda dari tahun 2014 hingga 2018 berfluktuasi, dapat dilihat pada total penjualan tahun 2014 hingga tahun 2017 terjadi penurunan penjualan sebesar 9,19 persen pada tahun 2015, pada tahun 2016 menurun sebesar 15,35 persen, pada tahun 2017 mengalami penurunan kembali sebesar 12,0 persen dan pada tahun 2018 terjadi peningkatan sebesar 15,20 persen. Dengan terjadinya penurunan penjualan ini membuat Honda harus bekerja lebih keras untuk meningkatkan kembali jumlah penjualan produknya, upaya kearah itu dilakukan studi atau penelitian dengan maksud mencari sejumlah informasi mengenai faktor apa saja yang mempengaruhi terhadap konsumen dalam melakukan niat pembelian ulang pada produk sepeda motor merek Honda.

Dilihat dari pencapaiannya saat ini Honda dapat dikatakan berhasil dalam memasuki pasar produk sepeda dari jenis motor jenis bebek hingga motor jenis skutik, hal tersebut membuat Honda harus terus meningkatkan kapasitas produksi produknya untuk memenuhi permintaan produk yang tinggi, disamping itu teknologi yang terdapat pada sepeda motor Honda juga sangat mempengaruhi permintaan terhadap produknya karena banyak fitur-fitur dan teknologi yang tidak ada pada sepeda motor lainnya yang dapat menjadi keunggulan produknya.

Berhasilnya Honda saat ini tidak lepas dari fakta yang ada saat ini bahwa Honda bukanlah yang pertama dalam pasar motor bebek atau motor skutik di Indonesia ditambah persaingan yang sangat ketat saat ini yang seketika para pesaingnya dapat memberikan ancaman. Sehingga mereka dituntut harus dapat berinovasi dengan produk-produknya dan lebih meningkatkan kinerja perusahaannya. 
Dengan banyaknya produsen sepeda motor di Indonesia menyebabkan masyarakat sulit dalam memilih produk yang tepat untuk mereka, para produsen harus berusaha lagi dalam menentukan konsep pemasaran yang tepat, salah satu cara dengan meningkatkan niat pembelian ulang pada produknya, dimana pembelian ulang yang dilakukan oleh konsumen diharapkan akan dapat lebih meningkatkan omset penjualan suatu produk.

Agar masyarakat dapat melakukan pembelian ulang, salah satu caranya adalah produsen harus lebih memperbaiki kualitas daripada produk-produknya, (Herawati, 2013) mengatakan kualitas yang baik dari suatu produk sangat mempengaruhi terhadap niat pembelian ulang konsumen itu sendiri. Menurut Arumsari \& Khasanah (2012) kualitas produk yang baik merupakan harapan dari pada konsumen yang harus dipenuhi oleh perusahaan. Sedangkan menurut Suardi (2003), kualitas produk memiliki peranan yang sangat penting bagi konsumen dalam memilih dan membeli suatu produk karena kualitas merupakan derajat atau tingkat karakteristik yang melekat pada produk yang mencukupi persyaratan atau keinginan.

Menurut Dewi \& Warmika (2017), untuk meraih pangsa pasar yang lebih besar perusahaan melakukan berbagai strategi untuk menciptakan keunggulan dalam bersaing. Salah satunya adalah dengan memastikan kualitas produk memenuhi harapan konsumen, sehingga dapat dikatakan seorang konsumen menilai suatu produk berdasarkan kualitas dari produk tersebut, Kurniawan et al. (2007) menyatakan di dalam mengembangkan sebuah produk, produsen harus menentukan mutu yang akan mendukung posisi produk itu di pasaran. Jika dianggap sudah memuaskan konsumen dalam memenuhi kebutuhan dan keinginannya, tentu konsumen tersebut nantinya akan melakukan pembelian ulang. Namun di satu sisi konsumen mengharapkan sesuatu yang lebih bukan hanya sekedar membeli dengan hanya melihat kualitas produknya, namun mereka lebih mengharapkan hal lain seperti pelayanan dan kualitas layanan tersebut

Kualitas layanan saat ini menjadi salah satu kunci sukses dari setiap bisnis. Kualitas ini diberikan kepada konsumen untuk memenuhi ekspektasi konsumen dengan menyediakan produk dan pelayanan pada suatu tingkat harga yang dapat diterima dan menciptakan "nilai" bagi konsumen serta menghasilkan profit bagi perusahaan nantinya (Bressolles \& Durrieu, 2011). Menurut (Parasuraman et al., (1988) kualitas layanan dapat dilihat dari lima dimensi antara lain: bukti fisik, keandalan, daya tanggap, jaminan, dan empati. Jadi tingkat kepuasan konsumen terhadap layanan suatu perusahaan dapat dilihat dari kepuasan konsumen terhadap kelima dimensi layanan yang ditawarkan oleh perusahaan tersebut.

Dalam melakukan pelayanan kepada konsumen, pelanggan yang mengalami ketidakpuasan terhadap pelayanan yang diterimanya, cenderung akan memberikan informasi yang negatif kepada orang lain terhadap jasa yang diterimanya tersebut (Siburian \& Zainurossalamia, 2016). Informasi yang negatif mengenai perusahaan akan berdampak pada citra perusahaan sehingga pelanggan beralih menggunakan produk pesaingnya yang dianggap lebih baik dari pelayan produk atau jasa sebelumnya. Intensitas persaingan dan jumlah pesaing tersebut membuat perusahaan harus lebih memperhatikan kebutuhan dan keinginan konsumen dan berusaha memenuhi keinginan harapan konsumen (Saidani \& Arifin, 2012). 
Dengan memberikan pelayanan yang maksimal, diharapkan dapat memberikan kepuasan kepada konsumen (Mulyono, 2007).

Dalam perkembangannya setiap perusahaan akan bersaing dalam menarik konsumen untuk menggunakan produk yang di produksi tidak lagi terbatas pada fungsi awal produk tersebut bagi konsumen, tetapi sudah dikaitkan dengan merek yang dapat memberikan citra khusus bagi konsumen (Kiseleva et al., 2016). Kekuatan citra merek suatu produk yang dimiliki oleh suatu perusahaan merupakan hasil dari penerapan strategi yang baik dalam pembentukan citra merek, sehingga dalam memutuskan melakukan niat pembelian ulang, salah satu faktor yang perlu dipertimbangkan adalah citra merek, dimana konsumen harus memilih perusahaan yang memiliki citra merek yang baik yang dapat membuat konsumen memutuskan melakukan niat pembelian ulang (Ali et al., 2018).

Citra merek yang ada suatu produk saat ini menjadi salah satu perhatian dan pertimbangan konsumen dalam memutuskan membeli produk, merek saat ini bukanlah hanya sekedar nama atau simbol saja, merek menjadi satu pembeda suatu produk dari produk lainnya Adriani \& Sembiring (2013). Menurut (Tjiptono, 2008), citra merek yaitu diskripsi tentang asosiasi dan keyakinan konsumen terhadap merek tertentu. Pilihan konsumen pada suatu merek produk tergantung pada citra yang melekat pada produk tersebut. Ramadhan et al. (2017), mengatakan citra merek yang kuat mengakibatkan konsumen memiliki asumsi positif terhadap merek dari produk yang ditawarkan sehingga konsumen tidak akan ragu untuk membeli produk yang ditawarkan oleh perusahaan, nantinya perusahaan tersebut harus mampu memberikan yang terbaik yang sesuai kebutuhan dan keinginan konsumen. Untuk itu, perusahaan harus bisa membangun merek yang lebih baik dari pesaing-pesaingnya, sehingga perusahaaan nantinya akan dihadapkan pada bagaimana cara agar konsumen tersebut dapat membentuk niat untuk membeli ulang merek yang disukai.

Pemasaran dengan menjalin hubungan secara jangka panjang dengan konsumen agar diperoleh kesesuaian antara pemasar dengan konsumen sehingga konsumen merasakan puas dan pemasar mendapatkan implikasinya, yaitu pembelian berulang (usage intention). Terdapat perbedaan antara pembelian aktual dan niat pembelian ulang. Bila pembelian aktual adalah pembelian yang benar-benar dilakukan oleh konsumen, maka niat pembelian ulang adalah niat untuk melakukan pembelian kembali pada kesempatan mendatang.

Dalam penelitian ini dipilih variabel kualitas produk, kualitas layanan dan citra merek sebagai fokus dari penelitian. Penelitian difokuskan pada variabel tersebut karena diduga variabel tersebut memiliki pengaruh yang signifikan terhadap niat pembelian ulang (studi pada Dealer Astra Motor Center Denpasar).

Perilaku konsumen merupakan suatu tindakan yang ditunjukan oleh konsumen dalam hal mencari, menukar, menggunakan, menilai, mengatur barang atau jasa yang mereka anggap akan memuaskan kebutuhan mereka. Swastha dan Perilaku konsumen menyatakan bahwa kegiatan-kegiatan individu yang secara langsung terlibat dalam mendapatkan dan mempergunakan barang dan jasa, termasuk didalamnya proses pengambilan keputusan pada persiapan dan penentuan kegiatan-kegiatan tersebut. Perilaku konsumen adalah perilaku yang ditunjukan oleh konsumen dalam mencari, membeli, mengevaluasi, menggunakan 
dan membuang produk dan jasa yang diharapkan akan memenuhi berbagai kebutuhannya.

Produk didefinisikan sebagai sesuatu yang dapat ditawarkan ke dalam pasar untuk diperhatikan, dimiliki, dipakai, atau dikonsumsi sehingga dapat memuaskan keinginan atau kebutuhan. Salah satu tujuan adanya kualitas produk adalah untuk mengetahui perilaku konsumen dengan cara mempengaruhi dalam pilihannya untuk menggunakan produk tersebut sehingga hal ini dapat memudahkan konsumen untuk mengambil sebuah keputusan dalam melakukan pembelian. Kualitas dapat dikatakan sebagai mutu dari atribut atau sifat-sifat sebagaimana dideskripsikan dari dalam produk dan jasa yang bersangkutan. Kualitas biasanya berhubungan dengan manfaat atau kegunaan serta fungsi dari suatu produk dapat dikatakan baik apabila sesuai dengan ekspektasi pelanggannnya. Kualitas merupakan faktor yang terdapat dalam suatu produk yang menyebabkan produk tersebut bernilai sesuai dengan maksud untuk apa produk itu diproduksi. Arti dari kualitas produk adalah kemampuan sebuah produk dalam memperagakan fungsinya, hal itu termasuk keseluruhan durabilitas, reliabilitas, ketepatan, kemudahan pengoperasian dan reparasi produk juga atribut produk lainnya.

Kualitas merupakan suatu kondisi dinamis yang berhubungan dengan produk, jasa, manusia, proses dan lingkungan yang memenuhi atau melebihi harapan. Definisi kualitas jasa berpusat pada upaya pemenuhan kebutuhan dan keinginan konsumen serta ketetapan penyampaian untuk mengurangi harapan konsumen. Kualitas jasa adalah tingkat keunggulan yang diharapkan dan pengendalian atas tingkat keunggulan tersebut untuk memenuhi keinginan pelanggan. Menurut Kualitas layanan merupakan ukuran seberapa baik tingkat pelayanan yang diberikan perusahaan penyedia jasa sesuai dengan harapan pelanggan. Kualitas layanan memiliki dampak tidak hanya pada pemasok atau distribusi, karyawan, pelanggan saja tetapi juga mempengaruhi seluruh bisnis dan pertumbuhan organisasi.

Pembelian ulang adalah suatu perilaku di mana konsumen membeli kembali produknya yang sebelumnya dibeli. Niat beli ulang merupakan tindakan pasca pembelian yang disebkan oleh adanya kepuasan yang dirasakan konsumen atas produk yang telah dibeli atau dikonsumsi sebelumnya. Jika produknya sesuai dengan keinginannya maka konsumen akan kembali membeli produk tersebut. Niat beli ulang (repurchase intention) adalah rencana konsumen yang mendorong kesediaannya untuk melakukan pembelian kembali atas produk yang telah dibelinya. Pembelian ulangan biasanya menandakan bahwa produk memenuhi persetujuan konsumen dan bahwa ia bersedia memakainya lagi dan dalam jumlah yang besar.

Pembelian kembali sebagai suatu kegiatan membeli kembali yang dilakukan oleh konsumen terhadap suatu produk dengan merek yang sama tanpa diikuti oleh perasaan yang berarti terhadap produk tersebut.Sebagian besar pembelian akan terulang seiring dengan waktu. Ketika pembelian kembali muncul ada dua kemungkinan, yaitu pembelian yang diulangi dalam rangka memecahkan masalah (repeated problem solving), dan kebiasaan pengambilan keputusan (habitual decision making). 
Menurut Pratiwi (2017), pemasaran dengan menjalin hubungan secara jangka panjang dengan konsumen agar diperoleh kesesuaian antara pemasar dengan konsumen sehingga konsumen merasakan puas dan pemasar mendapatkan implikasinya, yaitu pembelian berulang (usage intention). Terdapat perbedaan antara pembelian aktual dan niat pembelian ulang. Bila pembelian aktual adalah pembelian yang benar-benar dilakukan oleh konsumen, maka niat pembelian ulang adalah niat untuk melakukan pembelian kembali pada kesempatan mendatang (Kurniawan et al., 2007).

Dalam penelitian ini dipilih variabel kualitas produk, kualitas pelayanan dan citra merek sebagai fokus dari penelitian. Penelitian difokuskan pada variabel tersebut karena diduga variabel tersebut memiliki pengaruh yang signifikan terhadap niat pembelian ulang (studi pada Dealer Astra Motor Center Denpasar). Menurut Kotler \& Keller (2016) arti dari kualitas produk adalah kemampuan sebuah produk dalam memperagakan fungsinya, hal itu termasuk keseluruhan durabilitas, reliabilitas, ketepatan, kemudahan pengoperasian dan reparasi produk juga atribut produk lainnya.

Ismail \& Yusof (2009) kualitas layanan merupakan ukuran seberapa baik tingkat pelayanan yang diberikan perusahaan penyedia jasa sesuai dengan harapan pelanggan. Menurut Kotler (2011) citra merek adalah serangkaian keyakinan atau kepercayaan yang dipegang konsumen terhadap produk tertentu. Palma (2016), mengatakan bahwa niat beli ulang merupakan tindakan pasca pembelian yang disebkan oleh adanya kepuasan yang dirasakan konsumen atas produk yang telah dibeli atau dikonsumsi sebelumnya. Jika produknya sesuai dengan keinginannya maka konsumen akan kembali membeli produk tersebut.

$\mathrm{H}_{1}$ : Kualitas produk berpengaruh positif dan signifikan terhadap niat pembelian ulang

$\mathrm{H}_{2}$ : Kualitas layanan perpengaruh positif dan signifikan terhadap niat pembelian ulang

$\mathrm{H}_{3}$ : Citra merek berpengaruh positif dan signifikan terhadap niat pembelian ulang.

\section{METODE PENELITIAN}

Desain penelitian ini merupakan penelitian asosiatif, karena bertujuan untuk mengetahui pengaruh antara variabel kualitas produk, kualitas layanan dan citra merek terhadap niat pembelian ulang. Penelitian ini dilakukan di Dealer Astra Motor Center Denpasar yang beralamat di Jalan HOS Cokroaminoto No. 80 Ubung, pemilihan lokasi ini agar mendapatkan responden yang tepat dan juga ingin mengetahui apa yang mempengaruhi masyarakat dalam melakukan niat pembelian produk sepeda motor merek Honda, serta diharapkan dapat memberikan kontribusi dalam meningkatkan penjualaan produk sepeda motor merek Honda. Objek penelitian dari penelitian ini adalah pengaruh kualitas produk, kualitas layanan dan citra merek terhadap niat pembelian ulang (studi pada dealer Astra Motor Center Denpasar). Dalam penelitian ini variabel variabel yang dianalisis dapat dibagi menjadi dua yaitu variabel bebas dan variabel terikat. 
Berdasarkan kajian penelitian terdahulu dan hipotesis yang sudah dirumuskan, maka model konseptual yaitu:

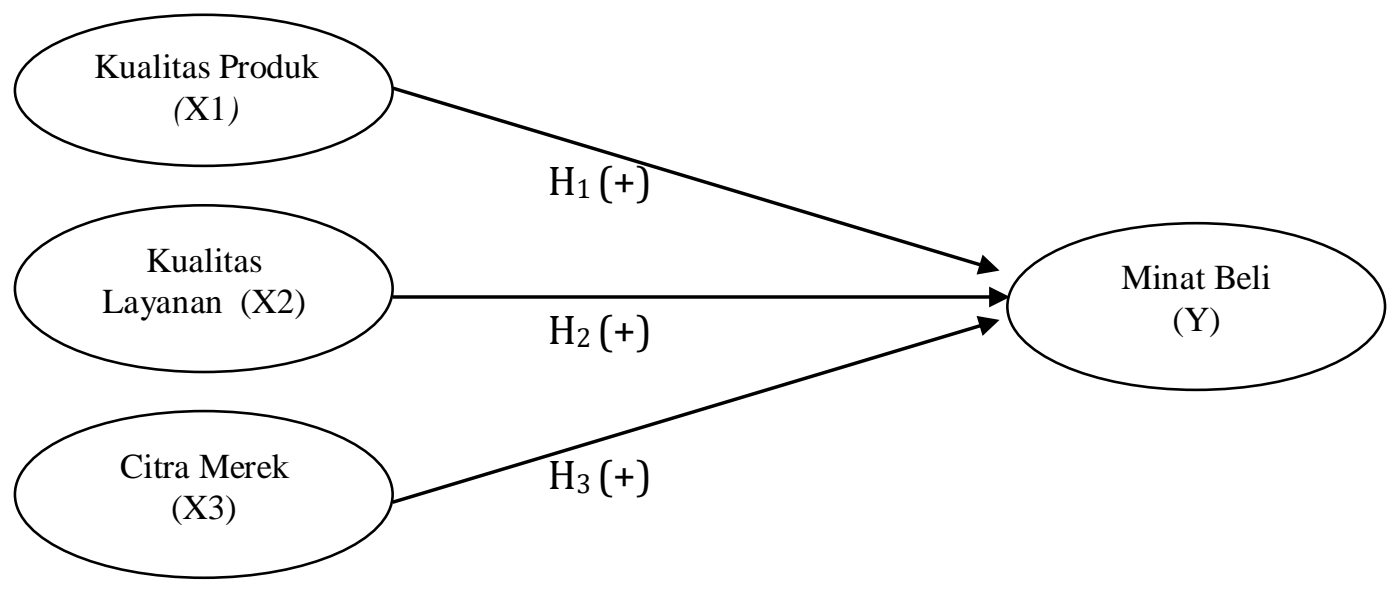

\section{Gambar 1. Kerangka Konseptual}

Sumber : kajian penelitian terdahulu

Variabel bebas dalam penelitian ini yaitu kualitas produk $\left(\mathrm{X}_{1}\right)$ terdiri atas 7 indikator yang diadopsi dari penelitian Saidani \& Arifin (2012) dan Mullins (2005) yaitu kinerja $\left(X_{1.1}\right)$, daya tahan $\left(X_{1.2}\right)$, kesesuaian dengan spesifikasi $\left(X_{1.3}\right)$, fitur $\left(\mathrm{X}_{1.4}\right)$, reliabilitas $\left(\mathrm{X}_{1.5}\right)$, estetika $\left(\mathrm{X}_{1.6}\right)$, kesan kualitas $\left(\mathrm{X}_{1.7}\right)$. Kualitas Layanan $\left(\mathrm{X}_{2}\right)$ terdiri atas 5 dimensi yang diadopsi dari penelitian Parasuraman dalam Tjiptono (2005) yaitu bukti fisik $\left(X_{2.1}\right)$, keandalan $\left(X_{2.2}\right)$, daya tanggap $\left(\mathrm{X}_{2.3}\right)$, jaminan $\left(\mathrm{X}_{2.4}\right)$, dan empati $\left(\mathrm{X}_{2.5}\right)$. Citra merek $\left(\mathrm{X}_{3}\right)$ terdiri atas 3 indikator yang diadopsi dari penelitian Plumer dalam Wijaya (2011) yaitu atribut produk $\left(\mathrm{X}_{3.1}\right)$, manfaat $\left(\mathrm{X}_{3.2}\right)$, dan kepribadian $\left(\mathrm{X}_{3.3}\right)$. Variabel terikat dalam penelitian ini yaitu Niat pembelian ulang (Y)terdiri atas 3 Indikator menurut Pradini (2011) yaitu frekuensi pembelian $\left(\mathrm{Y}_{1.1}\right)$, komitmen pelanggan $\left(\mathrm{Y}_{1.2}\right)$, rekomendasi positif $\left(\mathrm{Y}_{1.3}\right)$.

Kualitas produk merupakan keseluruhan ciri atau sifat barang dan jasa yang berpengaruh pada kemampuannya dalam memenuhi kebutuhan yang dinyatakan maupun yang tersirat $\left(\mathrm{X}_{1}\right)$ Indikator dari kualitas produk yaitu : Kinerja merupakan hasil yang didapatkan setelah menggunakan produk sepeda motor merek Honda, daya tahan merupakan berapa lama umur produk bertahan sebelum produk Honda tersebut harus diganti, kesesuaian dengan spesifikasi merupakan sejauh mana produk memenuhi spesifikasi atau tidak ditemukannya cacat pada produk Honda, reliabilitas merupakan probabilitas bahwa produk Honda akan bekerja dengan memuaskan atau tidak dalam periode waktu tertentu, estetika yaitu berhubungan dengan bagaimana penampilan produk sepeda motor merek Honda, dan kesan kualitas merupakan hasil dari penggunaan pengukuran yang dilakukan secara tidak langsung karena terdapat kemungkinan bahwa konsumen tidak mengerti atau kekurangan informasi atas produk sepeda motor merek Honda yang bersangkutan. 
Kualitas layanan merupakan seberapa jauh perbedaan antara kenyataan dan harapan pelanggan atas pelayanan yang mereka terima $\left(\mathrm{X}_{2}\right)$. Indikator kualitas pelayanan yaitu: bukti fisik meliputi fasilitas fisik (gedung, gudang dan lain sebagainya), perlengkapan dan peralatan yang digunakan dan juga penampilan karyawan Honda, keandalan memberikan pelayanan secara akurat dan terpercaya berarti ketepatan waktu, pelayanan yang sama untuk semua pelanggan tanpa kesalahan, daya tanggap memberikan pelayanan yang cepat (responsif) dan tepat kepada pelanggan dengan penyampaian inforrmasi yang jelas, jaminan yaitu pengetahuan, kesopanan dan kemampuan para pegawai perusahaan untuk menumbuhkan rasa percaya pada pelanggan kepada perusahaan, dan empati yaitu perhatian yang tulus dan bersifat individual yang diberikan kepada pelanggan dengan berupaya memahami keinginan konsumen.

Citra merek merupakan persepsi tentang sebuah merek yang dicerminkan oleh asosiasi merek yang ada di dalam ingatan konsumen $\left(\mathrm{X}_{3}\right)$. Citra Merek adalah persepsi dan keyakinan yang dilakukan oleh konsumen, seperti tercermin dalam asosiasi yang terjadi dalam memori konsumen. Indikator citra merek yaitu : atribut produk merupakan informasi atau fasilitas yang terdapat pada sebuah produk Honda, manfaat merupakan hasil yang didapat dari apa yang sudah konsumen gunakan, dan kepribadian merupakan ciri khas yang terdapat didalam merek itu sendiri, yang dapat membuat konsumen gampang untuk mengingatnya.

Niat pembelian ulang merupakan kecenderungan konsumen untuk membeli suatu merek atau mengambil suatu tindakan yang berhubungan dengan niat pembelian produk kembali yang telah dilakukan dimasa lalu. Indikator niat pembelian ulang yaitu : frekuensi pembelian merupakan seberapa besar tingkat keinginan konsumen untuk melakukan pembelian secara berulang, komitmen pelanggan merupakan seberapa besar tingkat keinginan konsumen untuk melakukan pembelian secara berulang, dan rekomendasi positif merupakan memberikan suatu pendapat atau sebuah informasi yang baik setelah konsumen tersebut menggunakan suatu produk kepada konsumen yang lain.

Dalam penelitian ini digunakan dua jenis data menurut sifatnya yaitu data kuantitatif dan data kualitatif. Data kuantitatif merupakan data yang berbentuk angka-angka atau data-data kualitatif yang diangkakan (Sugiyono, 2010:14). Data kuantitatif dalam penelitian ini berupa data jumlah penjualan sepeda motor merek Honda di Kota Denpasar serta hasil kuesioner yang berupa jawaban responden yang diukur dengan skala likert. Data kualitatif merupakan data yang dinyatakan dalam bentuk kalimat, skema atau gambaran terhadap permasalah yang dibahas dalam penelitian ini (Sugiyono, 2010:14). Data kualitatif dalam penelitian ini adalah produk-produk yang dijual di dealer resmi Honda.

Menurut sumbernya, dalam penelitian ini menggunakan sumber data primer dan sumber data sekunder. Data primer mengacu pada informasi yang diperoleh langsung dari sumbernya yang berkaitan dengan variabel yang diteliti dan masih perlu diolah lebih lanjut agar dapat memberikan hasil bagi penelitian. Data primer yang digunakan dalam penelitian ini yaitu melalui penyebaran kuisioner. Data sekunder mengacu pada informasi yang dikumpulkan dari sumber yang telah ada. Data sekunder yang dikumpulkan bersumber dari dokumen atau catatan yang ada 
di dealer resmi sepeda motor merek Honda di Denpasar, seperti buku catatan penjualan.

Variabel yang digunakan dalam penelitian ini antara lain variabel bebas dan variabel terikat yang diukur menggunakan indikator sebagai berikut

Tabel 2.

Rangkuman Variabel dan Indikator Penelitian

\begin{tabular}{|c|c|c|c|}
\hline No & Variabel & Indikator & Sumber \\
\hline 1. & Kualitas produk & $\begin{array}{ll}\text { 1. } & \text { Kinerja }\left(\mathrm{X}_{1.1}\right) \\
\text { 2. } & \text { Daya tahan }\left(\mathrm{X}_{1.2}\right) \\
\text { 3. } & \text { Kesesuaian dengan spesifikasi }\left(\mathrm{X}_{1.3}\right) \\
\text { 4. } & \text { Fitur }\left(\mathrm{X}_{1.4}\right) \\
\text { 5. } & \text { Reliabilitas }\left(\mathrm{X}_{1.5}\right) \\
\text { 6. } & \text { Estetika }\left(\mathrm{X}_{1.6}\right) \\
\text { 7. } & \text { Kesan kualitas }\left(\mathrm{X}_{1.7}\right)\end{array}$ & $\begin{array}{l}\text { Mullins } \\
(2005: 422)\end{array}$ \\
\hline 2. & Kualitas layanan & $\begin{array}{ll}\text { 1. } & \text { Bukti fisik }\left(X_{2.1}\right) \\
\text { 2. } & \text { Keandalan }\left(X_{2.2}\right) \\
\text { 3. } & \text { Daya tanggap }\left(X_{2.3}\right) \\
\text { 4. } & \text { Jaminan }\left(X_{2.4}\right) \\
\text { 5. } & \text { Empati }\left(X_{2.5}\right)\end{array}$ & $\begin{array}{l}\text { Setyorini, } \\
\text { (2011) }\end{array}$ \\
\hline 3. & Citra Merek & $\begin{array}{ll}\text { 1. } & \text { Atribut produk }\left(X_{3.1}\right) \\
\text { 2. } & \text { Manfaat }\left(X_{3.2}\right) \\
\text { 3. } & \text { Kepribadian }\left(X_{3.3}\right)\end{array}$ & $\begin{array}{l}\text { Plummer } \\
(2011)\end{array}$ \\
\hline 4 & $\begin{array}{c}\text { Niat Pembelian } \\
\text { Ulang }\end{array}$ & $\begin{array}{l}\text { 1. Frekuensi pembelian }\left(\mathrm{Y}_{.1}\right) \\
\text { 2. Komitmen pelanggan }\left(\mathrm{Y}_{.2}\right) \\
\text { 3. }\end{array}$ & Pradini (2011) \\
\hline
\end{tabular}

Sumber: Kajian penelitian sebelumnya, 2020

Dalam melakukan penelitian tidak lepas dari obyek sebagai sasaran penelitian yang biasa disebut populasi. Populasi sebagai keseluruhan subyek penelitian. Populasi dalam penelitian ini adalah seluruh konsumen pria dan wanita yang berada di dealer Astra Motor Center Denpasar dan berniat melakukan pembelian ulang produk sepeda motor merek Honda di dalam jangka waktu dua tahun terakhir dan bertempat tinggal di Kota Denpasar. Sampel adalah bagian dari populasi yang terpilih untuk berpartisipasi dalam studi. Dalam penelitian ini yang dijadikan sampel adalah seluruh konsumen yang memenuhi kriteria tertentu yang sesuai dengan peneliti lakukan pada Dealer Astra Motor Center Denpasar. Untuk memperoleh hasil ukuran sampel yang baik responden yang diambil untuk menjawab kuisioner dapat ditentukan berkisar antara 5-10 kali jumlah indikator yang diteliti. Jumlah indikator dalam penelitian ini adalah sebanyak 18 butir pernyataan sehingga banyaknya responden yang diambil sebagai sampel 7 x $18=$ 126 responden.

Pengambilan sampel ini menggunakan metode purposive sampling, yaitu penentuan sampel dengan pertimbangan tertentu, anggota populasi dipilih sebagai sampel adalah konsumen laki-laki dan perempuan yang sedang berada di Dealer Astra Motor Center Denpasar yang minimal berpendidikan SMA atau sederajat, berdomisili di kota Denpasar dan sudah pernah melakukan pembelian dengan pertimbangan mampu menjawab kuesioner secara objektif dan sebelumnya sudah 
pernah melakukan pembelian sepeda motor merek Honda di Dealer Astra Motor Center Denpasar.

Metode pengumpulan data yang digunakan dalam penelitian ini yaitu wawancara adalah cara pengumpulan data yang dilakukan dengan bertanya dan mendengarkan jawaban langsung dari sumber data. Pada penelitian ini metode wawancara yang digunakan adalah wawancara tidak terstruktur. Wawancara tidak terstruktur sering digunakan dalam penelitian untuk mendapatkan informasi awal tentang berbagai isu atau permasalahan yang ada pada objek, sehingga peneliti dapat menentukan secara pasti permasalahan atau variabel apa yang harus diteliti. Serta tanya jawab langsung dilakukan dengan pihak perusahaan. Kuesioner merupakan suatu teknik pengumpulan data dengan memberikan daftar pertanyaan atau pernyataan tertulis kepada responden untuk dijawab. Dalam hal ini mengenai pengaruh kualitas produk dan citra merek terhadap niat pembelian ulang (studi pada Dealer Astra Motor Center Denpasar). Selanjutnya, kuisioner diukur dengan skala likert. Skala ini mengukur sikap, pendapat, dan persepsi seseorang atas sebuah fenomena sosial.

Skala pengukuran adalah kesepakatan yang digunakan sebagai acuan untuk menentukan panjang pendeknya interval yang ada di dalam alat ukur, sehingga alat ukur tersebut bila digunakan dalam pengukuran akan menghasilkan data kuntiatif. Skala pengukuran yang digunakan adalah skala likert digunakan untuk mengukur sikap, persepsi, dan pendapat seseorang atau kelompok. Skala likert yang digunakan dari rentang angka 1 sampai 5 yang diberikan skor yaitu, jawaban sangat setuju $(\mathrm{SS})=5$, jawaban setuju $(\mathrm{S})=4$, jawaban kurang setuju $(\mathrm{KS})=3$, jawaban tidak setuju (TS) $=2$, dan jawaban sangat tidak setuju $\quad($ STS $)=1$.

Data yang dikumpulkan dalam penelitian ini dianalisis dengan cara regresi linier berganda. Analisis ini dipakai untuk mengetahui ketergantungan suatu variable terikat dengan satu atau lebih variabel bebas. Dalam analisis dibantu dengan program komputer statistical package for the social scince (SPSS). Bentuk umum persamaan linear berganda adalah sebagai berikut.

$$
Y=\alpha+\beta_{1} X_{1}+\beta_{2} X_{2}+\beta_{3} X_{3}+\ell_{i}
$$

$$
\begin{aligned}
& \text { Keterangan: } \\
& \mathrm{Y} \quad=\text { Niat Pembelian Ulang } \\
& \alpha=\text { Konstanta } \\
& \beta=\text { Koefisien Regresi } \\
& \mathrm{X}_{1} \quad=\text { Kualitas Produk } \\
& \mathrm{X}_{2} \quad=\text { Kualitas Pelayanan } \\
& \mathrm{X}_{3} \quad=\text { Citra Merek } \\
& \ell_{\mathrm{i}} \quad=\text { Variabel Pengganggu }
\end{aligned}
$$

\section{HASIL DAN PEMBAHASAN}

PT Astra International - Honda (Astra Motor) adalah salah satu perusahaan Astra International yang bergerak di bidango perations dengan produk sepeda motor Honda. Honda Astra Motor merupakan pelopor industri sepeda motor di 
Indoesia. Didirikan pada 11 Juni 1971 dengan nama awal PT. Federal Motor. PT. Federal Motor saat itu hanya merakit, sedangkan komponennya diimpor dari jepang dalam bentuk completly knock dwon (CKD). Tipe sepeda motor yang pertama kali diproduksi honda adalah tipe bisnis, S90 Z bermesin 4 tak dengan kapasitas 90cc. Jumlah produksi tahun pertama selama satu tahun hanya 1500 unit, namun melonjak menjadi 30.000 pada tahun berikutnya dan terus berkembang hingga saat ini.

Astra Motor, juga dikenal sebagai Honda Sales Operations. Astra Motor merupakan brand yang diusung sebagai wajah perusahaan dalam menjalin hubungan dengan customer. Saat ini, Astra Motor dipimpin oleh Margono Tanuwijaya selaku CEO Astra Motor menggantikan (Alm.) Ronny Ramli yang meninggal pada awal 2010. Astra Motor memiliki dua jalur cara menjalin hubungan dengan para customer-nya, yang pertama adalah melalui dealer, yang ke dua adalah melalui sales office yang dikoordinasi dalam divisi retail Astra Motor.

Pada tahun 2001 seiring dengan perkembangan kondisi ekonomi serta tumbuhnya pasar sepeda motor, terjadi perubahan komposisi kepemilikan saham di pabrik sepeda motor Honda. Pada tahun 2001 PT. Federal Motor dan beberapa anak perusahaan yangmenjadi satu dengan nama PT. Astra Honda Motor. Komposisi kepemilikan sahamnya menjadi 50\% milik PT. Astra International Tbk dan 50\% menjadi milik Honda Motor Co. Japang Pada tahun 2014 Astra Honda Motor memiliki 4 fasilitas pabrik perakitan. Pabrik pertama berlokasi di Sunter Jakarta Utara yang juga sebagai kantor pusat, pabrik kedua berlokasi di Penggangsaan Dua (Kelapa Gading), dan pabrik ketiga berlokasi dikawasan MM 2100 Cikarang Barat (Bekasi), pabrik keempat ini merupakan fasilitas pabrik perakitan terbaru yang mulai beroperasi sejak tahun 2014. Pada tahun 2015 dengan keseluruhan fasilitas Astra Honda Motor saat ini memiliki kapasitas produksi 5.8 juta unit sepeda motor pertahunnya, untuk permintaan pasar sepeda motor di Indonesia yang terus meningkat.

Salah satu puncak prestasi yang berhasil diraih Astra Honda Motor adalah pencapaian produksi ke 50 juta pada tahun 2015. Prestasi ini merupakan prestasi pertama yang berhasil diraih oleh industri sepeda motor di Indonesia bahkan untuk tingkat ASEAN. Astra International terbentuk kerja sama dengan sejumlah perusahaan kelas dunia. Industri sepeda motor tanah air merupakan industri yang produktif karena permintaan pasar sepedaa motor domestik yang sangat besar setiap tahunya. Sepeda motor bagi masyarakat Indonesia masih merupakan solusi transportasi yang sangat diminati dikarenakan tingkat konsumsi bahan bakar, biaya perawatan yang relatif rendah, serta kepraktisan dalam menghadapi kemacetan dibeberapa kota besardi Indonesia. Menurut data AISI (Asosiasi Indusri Sepeda Motor Indonesia), pasar sepeda motor di Indonesia mencapai lebih dari 7,8 juta unit di tahun 2014dan merupakan pasar motor terbesar ketiga di dunia. Peranutama industri sepeda motor di tanah air yaitu Honda, Yamaha, Suzuki, dan Kawasaki. Di Indonesia sendiri, Honda Motor Japang memasarkan produkanya bekerjasama dengan PT. Astra International Tbk.

Sebagai salah satumain dealer, Astra Motor berperan dalam mengkoordinasi segala aktivitas marketing, logistik, dan termasuk promosi diregion. Astra Motor 
memiliki region-region yang dipimpin oleh region head sebagai pimpinan tertinggi di region tersebut. Region-region ini rutin berkoordinasi dan berinteraksi dengan Astra Motor Head Office yang terletak di kompleks Astra International, Jakarta.

Honda, melalui Astra Honda Motor (AHM), sebuah joint venture 50:50 yang didirikan sebagai prioritas penting di beberapa tahun terakhir untuk melayanipermintaan konsumen yang meningkat. Tidak hanya sebatas perluasan jaringan, Astra Motor juga membuktikan komitmennya untuk melayani konsumen dengan baik dan meningkatkan brand image pada umumnya, dan Astra Motor pada khususnya. Komitment ini membuktikan dengan eksekusi peremajaan outlet yang lias, meliput investasi pembaruan infrastruktur, eksterior, dan interior direct outlet Astra Motor.

Pertumbuhan konsumen sepeda motor meningkat luar biasa. Di tengahtengah persaingan yang begitu tajam akibat banyaknya merek pendatang baru, sepeda motor Honda yang sudah lama berada di Indonesia, dengan segala keunggulannya, tetap mendominasi pasar dan sekaligus memenuhi kebutuhan angkutan yang tangguh, irit dan ekonomis. Menjawab tantangan tersebut, organisasi yang berada di balik kesuksesan sepeda motor Honda di Indonesia terus memperkuat diri.

PT. Astra Honda Motor (AHM) merupakan sinergi keunggulan teknologi dan jaringan pemasaran di Indonesia, sebuah pengembangan kerja sama anatara Honda Motor Company Limited, Jepang, dan PT. Astra International Tbk, Indonesia. Keunggulan teknologi Honda Motor diakui di seluruh dunia dan telah dibuktikan dalam berbagai kesempatan, baik di jalan raya maupun di lintasan balap. Honda pun mengembangkan teknologi yang mampu menjawab kebutuhan pelanggan yaitu mesin "bandel" dan irit bahan bakar, sehingga menjadikannya sebagai pelopor kendaraan roda dua yang ekonomis. Tidak heran, jika harga jual kembali sepeda motor Honda tetap tinggi. AHM memiliki pengetahuan yang komprehensif tentang kebutuhan para pemakai sepeda motor di Indonesia, berkat jaringan pemasaran dan pengalamannya yang luas. AHM juga mampu memfasilitasi pembelian dan memberikan pelayanan purna jual sedemikian rupa sehingga brand Honda semakin unggul.

Adapun filosofi (Catur Darma) Visi dan Misi dari PT. Astra Honda Motor adalah sebagai berikut : (1) Filosofi (Catur Darma) yaitu menjadi milik yang bermanfaat bagi bangsa dan Negara, memberikan pelayanan kepada pelanggan , menghargai individu dan membina kerja sama, dan senantiasa mencapai yang terbaik. Struktur organisasi adalah suatu susunan dan hubungan antara tiap bagian serta posisi yang ada pada suatu organisasi atau perusahaan dalam menjalankan kegiatan oprasional untuk mencapai tujuan yang diharapkan dan diinginkan bersama. Struktur organisasi menggambarkan dengan jelas pemisahan kegiatan pekerjaan antara yang satu dengan yang lain dan bagaimana hubungan aktivitas dan fungsi dibatasi. Dalam struktur organisasi yang baik harus menjalankan hubungan wewenang siapa melapor kepada siapa, jadi terdapat satu pertanggung jawaban apa yang akan dikerjakan. 
Dalam penelitian ini karakteristik responden digambarkan mengenai jenis kelamin, umur, dan tingkat pendidikan responden. Adapun karakteristik yang terkumpul melalui pengumpulan kuisioner adalah sebagai berikut.

Tabel 3.

Karakteristik Responden

\begin{tabular}{|c|c|c|c|}
\hline NO & Karakteristik Responden & Jumlah (orang) & Persentase (\%) \\
\hline \multirow[t]{4}{*}{1.} & Jenis Kelamin & & \\
\hline & a. Laki-laki & 80 & 63,5 \\
\hline & b. Perempuan & 46 & 36,5 \\
\hline & Jumlah & 126 & 100 \\
\hline \multirow[t]{5}{*}{2.} & Umur & & \\
\hline & a. $20-25$ & 20 & 15,9 \\
\hline & b. $>25-30$ & 30 & 23,8 \\
\hline & c. $>30$ & 76 & 60,3 \\
\hline & Jumlah & 126 & 100 \\
\hline \multirow[t]{5}{*}{3.} & Tingkat Pendidikan & & \\
\hline & a. SMA & 30 & 23,8 \\
\hline & b. D3 & 46 & 36,5 \\
\hline & c. Sarjana & 50 & 39,7 \\
\hline & Jumlah & 126 & 100 \\
\hline \multirow[t]{7}{*}{4.} & Pekerjaan & & \\
\hline & a. Pelajar/Mahasiswa & 4 & 3,2 \\
\hline & b. PNS & 27 & 21,4 \\
\hline & c. Pegawai Swasta & 61 & 48,4 \\
\hline & d. Wiraswasta & 25 & 19,8 \\
\hline & e. Lainnya & 9 & 7,1 \\
\hline & Jumlah & 126 & 100 \\
\hline \multirow[t]{5}{*}{5.} & Tingkat Pendapatan & & \\
\hline & a. $\quad<$ Rp. 1.000 .000 & 6 & 4,8 \\
\hline & b. Rp. 1.000 .000 - Rp. 3.000 .000 & 40 & 31,7 \\
\hline & c. $>$ Rp. 3.000 .000 & 80 & 63,5 \\
\hline & Jumlah & 126 & 100 \\
\hline \multirow[t]{4}{*}{6.} & Frekuensi Pembelian & & \\
\hline & a. 2 kali & 120 & 95,4 \\
\hline & b. 3-5 kali & 6 & 4,8 \\
\hline & Jumlah & 126 & 100 \\
\hline
\end{tabular}

Sumber : Data primer, 2020

Tabel 3. menyatakan bahwa sebagian besar responden adalah laki-laki 80 orang dan sisanya adalah responden perempuan sebanyak 46 orang, sedangkan karakteristik responden berdasarkan umursebagian besar berumur $>30$ tahun, sebanyak 76 orang,dan terendahpada kelompok umur 20-25 Tahun sebanyak 20 orang. Pada tingkat pendidikan, sarjana merupakan responden terbanyak 50 orang, dan terendah adalah tingkat pendidikan SMA sebesar 30 orang. Pada tingkat pekerjaan pegawai swasta menjadi responden terbanyak berdasarkan karakteristik pekerjaan yaitu sebanyak 61 orang dan terendah pada tingkat pelajar/mahasiswa sebanyak 4 orang. Pada tingkat pendapatan penghasilan tertinggi sebesar $>\mathrm{Rp}$. 3.000.000 sebanyak 80 orang dan terendah < Rp. 1.000 .000 sebanyak 6 orang. Sedangkan pada tingkat frekuensi pembelian, responden yang pernah membeli sebanyak 2 kali memiliki jumlah terbanyak yaitu 120 orang. 
Uji validitas merupakan pengujian instrumen penelitian sebagai suatu derajat ketepatan alat ukur penelitian tentang inti atau arti sebenarnya yang diukur. Tinggi rendahnya validitas menunjukkan sejauh mana data yang terkumpul tidak menyimpang dari gambaran tentang variabel yang dimaksud. Suatu kuesioner dikatakan valid jika tiap butir pernyataan mampu mengungkapkan sesuatu yang akan diukur oleh kuesioner. Reliabilitas adalah derajat ketepatan, ketelitian atau keakuratan yang ditunjukkan oleh instrument pengukuran dimana pengujiannya dapat dilakukan secara internal, yaitu pengujian dengan menganalisis konsistensi butir-butir yang ada.

Tabel 4.

Rekapitulasi Hasil Uji Validitas dan Reliabilitas Instrumen Penelitian

\begin{tabular}{|c|c|c|c|c|c|}
\hline No. & Variabel & $\begin{array}{c}\text { Item } \\
\text { Pernyataan }\end{array}$ & $\begin{array}{c}\text { Pearson } \\
\text { Correlation }\end{array}$ & $\begin{array}{c}\text { Cronbach's } \\
\text { Alpha }\end{array}$ & Keterangan \\
\hline \multirow{7}{*}{1} & \multirow{7}{*}{$\begin{array}{l}\text { Kualitas produk } \\
\text { (X1) }\end{array}$} & X1.1 & 0,98 & \multirow{7}{*}{0,997} & Valid \\
\hline & & $\mathrm{X} 1.2$ & 0,997 & & Valid \\
\hline & & $\mathrm{X} 1.3$ & 0,98 & & Valid \\
\hline & & X1.4 & 0,997 & & Valid \\
\hline & & $\mathrm{X} 1.5$ & 0,997 & & Valid \\
\hline & & X1.6 & 0,997 & & Valid \\
\hline & & $\mathrm{X} 1.7$ & 0,997 & & Valid \\
\hline \multirow{5}{*}{2} & \multirow{5}{*}{$\begin{array}{c}\text { Kualitas } \\
\text { Layanan } \\
\text { (X2) }\end{array}$} & $\mathrm{X} 2.1$ & 0,981 & \multirow{5}{*}{0,984} & Valid \\
\hline & & $\mathrm{X} 2.2$ & 0,991 & & Valid \\
\hline & & $\mathrm{X} 2.3$ & 0,981 & & Valid \\
\hline & & $\mathrm{X} 2.4$ & 0,906 & & Valid \\
\hline & & $\mathrm{X} 2.5$ & 0,991 & & Valid \\
\hline \multirow{3}{*}{3} & \multirow{3}{*}{$\begin{array}{l}\text { Citra Merek } \\
\quad \text { (X3) }\end{array}$} & X3.1 & 0,989 & \multirow{3}{*}{0,977} & Valid \\
\hline & & X3.2 & 0,958 & & Valid \\
\hline & & X3.3 & 0,989 & & Valid \\
\hline \multirow{3}{*}{4} & \multirow{3}{*}{$\begin{array}{l}\text { Niat pembelian } \\
\text { (X4) }\end{array}$} & $\mathrm{Y} 1$ & 0,791 & \multirow{3}{*}{0,819} & Valid \\
\hline & & $\mathrm{Y} 2$ & 0,884 & & Valid \\
\hline & & $\mathrm{Y} 3$ & 0,901 & & Valid \\
\hline
\end{tabular}

Sumber : Data primer, 2020

Tabel 4. menunjukkan bahwa seluruh instrumen penelitian yang digunakan untuk mengukur variabel kualitas produk, kualitas layanan, citra merek danniat pembelian memiliki nilai koefisien korelasi dengan skor total seluruh item pernyataan lebih besar dari 0,30 dan memiliki koefisien Cronbach's Alpha lebih dari 0,60. Hal ini menunjukkan bahwa butir-butir pernyataan dalam instrument penelitian tersebut valid dan reliabel, sehingga layak digunakan sebagai instrument penelitian.

Uji multikolinearitas bertujuan untuk membuktikan atau menguji ada atau tidaknya hubungan yang linier (multikolinearitas) antara variabel bebas (independent) satu dengan variabel bebas yang lain. Berdasarkan hasil analisis diperoleh nilai tolerance untuk kedua variabel bebas lebih besar dari 0,1 
sedangkan, nilai VIF kurang dari 10. Jadi dapat dinyatakan bahwa, model uji tidak terdeteksi kasus multikolinearitas atau dapat dikatakan tidak ada multikolinearitas.

Uji normalitas bertujuan untuk menguji apakah suatu data berdistribusi normal atau tidak. Penentuan normal atau tidaknya distribusi data dapat dilakukan pengujian dengan menggunakan statistik Kolmogorov-Smirnov. Hasil uji menunjukkan bahwa nilai Asymp. Sig. 0,062. Oleh karena nilai Asymp. Sig. lebih besar dari alpha 5 persen maka, dapat dinyatakan bahwa model uji telah memenuhi syarat normalitas data.

Uji heterokedastisitas dilakukan untuk mengetahui bahwa pada model regresi 21 terjadi ketidaksamaan varian.Untuk mendeteksi ada atau tidaknya heterokedastisitas digunakan model glejser. Model ini dilakukan dengan meregresikan nilai absolute ei dengan variabel bebas. Berdasarkan hasil analisis data menunjukkan bahwa, ketiga variabel bebas tidak berpengaruh signifikan terhadap nilai variabel terikatnya (absolute ei). Hal ini ditunjukkan dari nilai signifikansi masing - masing variabel kualitas produk, kualitas layanan dan citra merek yaitu sebesar 0,$728 ; 0,750$ dan 0,127 diatas 0,05 .Jadi dapat dinyatakan bahwa, model uji terbebas dari kasus heterokedastisitas atau dapat dikatakan tidak ada heterokedastisitas.

Uji kelayakan model (uji F) bertujuan untuk menguji apakah semua variabel bebas berpengaruh terhadap variabel terikat dan untuk mengetahui model regresi yang digunakan dalam penelitian ini layak uji atau tidak. Berdasarkan hasil analisis data diperoleh nilai $\mathrm{F}$ statistik sebesar 98,134 dengansignifikansi 0,000. Nilai signifikansi yang lebih kecil dari 0,05 menunjukkan bahwa ada pengaruh antara variabel - variabel kualitas produk, kualitas layanan, citra merek secara simultan terhadap variabel niat pembelian ulang. Dengan demikian model dapat dikatakan fit (layak).

Analisis regresi linier berganda digunakan untuk mengetahui besarnya pengaruh variabel kualitas produk, kualitaslayanan, citra merek, sebagai variabel independen (variabel bebas) terhadap niat pembelian ulang (Y) yang berfungsi sebagai variabel dependen (variabel terikat).Adapun rangkuman dari hasil uji regresi linier berganda dapat ditunjukkan pada Tabel 5. sebagai berikut.

Tabel 5.

Pelaporan Hasil Uji regresi linier berganda

\begin{tabular}{|c|c|c|c|c|c|c|}
\hline & & & $\begin{array}{l}\text { dardized } \\
\text { icients }\end{array}$ & & & \\
\hline & Model & B & Std. Error & $\mathbf{T}$ & Sig & Ket \\
\hline 1 & Constant & 1,205 & .661 & 1.823 & 0,71 & Sig \\
\hline & Kualitas Produk & 0,145 & .019 & 7.809 & .000 & Sig \\
\hline & Kualitas Pelayanan & 0,140 & .027 & 5.223 & .000 & Sig \\
\hline & Citra Merk & 0,327 & .045 & 7.265 & .000 & Sig \\
\hline & are : 0,707 & & & & & \\
\hline & istik : 98, 134 & & & & & \\
\hline & ikansi : 0,000 & & & & & \\
\hline
\end{tabular}

Berdasarkan Tabel 5. diatas diketahui bahwa, persamaan regresinya adalah sebagai berikut : 
$\mathrm{Y}=1,205+0,145 \mathrm{X}_{1}+0,140 \mathrm{X}_{2}+0,327 \mathrm{X}_{3}$

Berdasarkan hasil persamaan diperoleh nilai $\alpha=1,205$ berarti apabila kualitas produk $\left(\mathrm{X}_{1}\right)$, kualitas layanan $\left(\mathrm{X}_{2}\right)$, dan citra merek $\left(\mathrm{X}_{3}\right)$ tidak mengalami perubahaan atau tetap maka niat pembelian ulang (Y) tidak mengalami perubahan. Nilai $b_{1}=0,145$ berarti apabila kualitas produk $\left(\mathrm{X}_{1}\right)$ naik dan kualitas layanan $\left(\mathrm{X}_{2}\right)$, citra merek $\left(\mathrm{X}_{3}\right)$ tidak berubah maka niat pembelian ulang $(\mathrm{Y})$ juga meningkat. Artinya setiap peningkatan kualitas produk dapat meningkatkan niat pembelian ulang. Nilai $b_{2}=0,140$ berarti apabila kualitas layanan $\left(X_{2}\right)$ naik dan kualitas produk $\left(\mathrm{X}_{1}\right)$, citra merek $\left(\mathrm{X}_{3}\right)$ tidak berubah maka niat pembelian ulang (Y) juga meningkat. Artinya setiap peningkatan kualitas layanan dapat meningkatkan niat pembelian ulang. Nilai $b_{3}=0,327$ berarti apabila citra merek $\left(\mathrm{X}_{3}\right)$ naik dan kualitas layanan $\left(\mathrm{X}_{2}\right)$, kualitas produk $\left(\mathrm{X}_{1}\right)$ tidak berubah maka niat pembelian ulang (Y) juga meningkat. Artinya setiap peningkatan citra merek dapat meningkatkan niat pembelian ulang.

Berdasarkan hasil uji $\mathrm{t}$ dan nilai signifikasi pada variabel kualitas produk $\left(\mathrm{X}_{1}\right)$ menunjukkan nilai sig lebih kecil dari 0,05 maka dapat disimpulkan bahwa, kualitas produk berpengaruh positif dan signifikan terhadap niat pembelian ulang (Y). Hasil penelitian memberikan makna bahwa semakin baik kualitas produk maka semakin tinggi niat pembelian, begitu sebaliknya semakin rendah kualitas produk maka semakin rendah niat pembelian ulang.

Hubungan antara konsep ini menjelaskan bagaimana hubungan antara kualitas produk dengan niat pembelian ulang. Kurniawan et al. (2007), menyatakan bahwa variabel kualitas produk telah terbukti secara empiris dan berpengaruh positif sehingga merupakan variabel yang penting dalam meningkatkan niat beli ulang produk Sakatonik Liver. Sedangkan menurut Saidani \& Arifin (2012), Variabel kualitas produk memiliki pengaruh langsung yang positif terhadap niat pembelian ulang pada pelanggan Ranch Market. Penelitian yang dilakukan oleh Ramadhan \& Santosa (2017), menyatakan bahwa kualitas produk berpengaruh positif terhadap minat beli ulang sepatu Nike running di Semarang. Menurut penelitian yang dilakukan oleh Evelina et al. (2012), menyatakan variabel citra merek (brand image), harga, kualitas produk dan promosi memiliki pengaruh yang positif dan signifikan terhadap keputusan pembelian produk kartu perdana Telkom flexi. Sedangkan penelitian menurut Nurlisa (2010) variabel citra merek (brand image), dan kualitas produk berpengaruh positif dan signifikan terhadap keputusan pembelian. Hasil penelitian Herawati (2013), Persepsi Kualitas Produk berpengaruh positif terhadap Niat Pembelian Ulang pada Private Label "Carrefour" di Carrefour.

Berdasarkan hasil uji $t$ dan nilai signifikasi pada variabel kualitas pelayanan $\left(\mathrm{X}_{2}\right)$ menunjukkan nilai sig lebih kecil dari 0,05 maka dapat disimpulkan bahwa, kualitas pelayanan berpengaruh positif dan signifikan terhadap niat pembelian ulang (Y). Hasil penelitian memberikan makna bahwa semakin baik kualitas layanan maka semakin tinggi niat pembelian ulang, semakin rendah kualitas layanan maka semakin rendah niat pembelian ulang.

Dari hasil penelitian yang dilakukan Saidani \& Arifin (2012), didapat bahwa variabel kualitas layanan juga memiliki pengaruh langsung yang positif dan 
signifikan terhadap minat beli ulang pelanggan ranch market pondok indah. Sedangkan hasil penelitian Ramadhan \& Santosa (2017) membuktikan bahwa kualitas layanan mempunyai pengaruh yang positif dan signifikan terhadap minat beli ulang pada sepatu Nike running di Semarang. Pradini (2011), kualitas layanan yang baik akan mendorong minat beli ulang konsumen. Dengan adanya pengenalan produk yang baik tempat yang nyaman dan pemberian gift dan service yang memadai, diharapkan mampu mendorong konsumen untuk membeli produk tersebut. Penelitian menurut Dwi (2011), kualitas produk merupakan mutu dari semua komponen-komponen yang membentuk produk, sehingga produk tersebut memiliki nilai tambah sehingga dapat di simpulkan kualitas produk berpengaruh positif yang signifikan terhadap minat beli ulang produk perlengkapan kunci di PT. Kenari Djaja Prima Semarang.

Berdasarkan hasil uji t dan nilai signifikasipada variabel citra merek $\left(\mathrm{X}_{3}\right)$ menunjukkan nilai sig lebih kecil dari 0,05 maka dapat disimpulkan bahwa, citra merek berpengaruh positif dan signifikan terhadap niat pembelian ulang(Y). Hasil penelitian memberikan makna bahwa semakin baik citra merek maka semakin tinggi niat pembelian ulang, begitu sebaliknya semakin rendah citra merek maka semakin rendah niat pembelian ulang.

Hasil penelitian Pradini (2011), menunjukan bahwa citra merek berpengaruh positif dan signifikan terhadap niat pembelian ulang, citra merek merupakan variabel yang sangat penting, hal ini dikarenakan keyakinan konsumen terhadap merek daripada Honda sudah sangat melekat dan benar-benar yakin bahwa merek tersebut bagus sehingga mempengaruhi niat pembelian ulang. Minat beli ulang sendri timbul karena adanya suatu aspek salah satunya citra merek pada suatu produk, minat beli ulang ulang terjadi ketika seseorang telah membeli suatu produk daan mengkonsumsinya lebih dari 1 kali pemesanan Ramadhan \& Santosa (2017). Menurut penelitian yang dilakukan oleh Evelina et al. (2012), menyatakan variabel citra merek (brand image), harga, kualitas produk dan promosi memiliki pengaruh yang positif dan signifikan terhadap keputusan pembelian produk kartu perdana telkom flexi. Sedangkan penelitian menurut Nurlisa (2010) variabel citra merek (brand image), dan kualitas produk berpengaruh positif dan signifikan terhadap keputusan pembelian.

\section{SIMPULAN}

Berdasarkan hasil pembahasan yang telah diuraikan, maka simpulan yang diperoleh yaitu pertama, kualitas produk berpengaruh positif dan signifikan terhadap niat pembelian ulang. Artinya dengan mempertahankan kualitas yang dimiliki produk Honda maka semakin tinggi niat pembelian ulang yang dilakukan oleh konsumennya. Kedua, kualitas pelayanan berpengaruh positif dan signifikan terhadap niat pembelian ulang. Artinya bahwa semakin baik kualitas layanan yang diberikan oleh perusahaan terhadap konsumen maka semakin tinggi niat pembelian ulang. Ketiga, citra merek berpengaruh positif dan signifikan terhadap niat pembelian ulang. Artinya bahwa semakin baik citra merek yang dimiliki perusahaan maka semakin tinggi niat pembelian ulang. 
Berdasarkan simpulan tersebut, maka saran yang dapat diberikan yaitu pada kualitas produk, Dealer Astra Motor Center Denpasar diharapkan lebih meningkatkan fitur-fitur yang ada pada produknnya saat ini, ini disebabkan kemajuan teknologi yang sangat pesat sehingga kebutuhan konsumen terhadap fitur-fitur yang diberikan pada produk yang diproduksinya semakin lengkap.

Pada kualitas layanan, Dealer Astra Motor Center Denpasar diharapkan dapat meningkatkan lagi pelayanannya dalam bidang kemudahan dalam melakukan perawatan produk sepeda motornya, dengan cara meningkatkan jumlah mekanik yang ada saat ini sehingga mempercepat konsumen dalam melakukan perawatan.

Pada citra merek, sepeda motor merek Honda dapat dikatakan menjadi market leader, ini tidak lepas dari citra merek yang sudah dibangunnya sejak lama. Dengan banyaknya merek yang ada saat ini Dealer Astra Motor Center harus lebih meningkatkan citra mereknya.

Pada niat Pembelian ulang, serta saat ini konsumen membeli produk Honda karena produk Honda sesuai dengan kebutuhan konsumen, pihak perusahaan harus lebih memberikan perhatian terhadap apa saja yang konsumen butuhkan agar kedepannya produk-produk yang di produksi oleh Honda dapat membantu masyarakat dalam melakukan aktivitasnya.

Bagi peneliti selanjutnya disarankan agar menambah ruang lingkup pengamatan untuk daerah yang lebih luas dan menambahkan variabel-variabel lain seperti: persepsi harga dan promosi, sehingga hasil yang didapatnya menjadi lebih representatif.

\section{REFERENSI}

Adriani, N., \& Sembiring, B. K. F. (2013). Analisis Strategi Merek Dan Citra Merek Terhadap Keputusan Pembelian Pada J . Co Donuts \& Coffee Cabang Cambridge City Square Medan. Media Informasi Manajemen, 1(2), 181-191.

Ali, H., Narulita, E., \& Nurmahdi, A. (2018). Saudi Journal Of Business And Management Studies ( Sjbms ) The Influence Of Service Quality, Brand Image And Promotion On Purchase Decision At Mcu Eka Hospital. Business And Management Studies. Https://Doi.Org/10.21276/Sjbms.2018.3.1.12

Arumsari, D., \& Khasanah, I. (2012). Pengaruh Kualitas Produk Dan Harga Terhadap Keputusan Pembelian Air Minum Dalam Kemasan ( Amdk ) Merek Aqua. Jurnal Ilmiah Prodi Manajemen Universitas Pamulang, 9(4), 94-101.

Bressolles, G., \& Durrieu, F. (2011). Service Quality, Customer Value And Satisfaction Relationship Revisited For Online Wine Websites. In 6th Awbr International Conference, Bem - Bordeaux Management School - France (Pp. 1-13). 
Dewi, N. N. K. A., \& Warmika, I. G. K. (2017). Pengaruh Internet Marketing, Brand Awareness, Dan Wom Communication Terhadap Keputusan Pembelian Produk Spa Bali Alus. E-Jurnal Manajemen Udayana, 6(10), 5580-5606.

Dwi, A. H. (2011). Analisis Pengaruh Kualitas Produk , Persepsi Harga, Dan Kualitas Layanan Terhadap Minat Beli Ulang Produk Perlengkapan Kunci Di Pt Kenari Djaja Prima Semarang. Jurnal Sains Pemasaran Indonesia, 10(1), 47-87. Https://Doi.Org/10.14710/Jspi.V10i1.47

Evelina, N., Dw, H., \& Listyorini, S. (2012). Pengaruh Citra Merek, Kualitas Produk, Harga, Dan Promosi Terhadap Keputusan Pembelian Kartu Perdana Telkomflexi (Studi Kasus Pada Konsumen Telkomflexi Di Kecamatan Kota Kudus Kabupaten Kudus). Diponegoro Journal Of Social And Politic, 1(1), $1-11$.

Herawati, V. (2013). Pengaruh Persepsi Kualitas Produk Terhadap Niat Pembelian Ulang Pada Private Label "Carrefour" Di Carrefour Melalui Kepuasan Konsumen Sebagai Variabel Mediasi. Jurnal Ilmiah Mahasiswa Manajemen, 1(3), 110-121.

Ismail, M. B., \& Yusof, Z. M. (2009). Demographic Factors And Knowledge Sharing Quality Among Malaysian Government Officers. In Innovation And Knowledge Management In Twin Track Economies Challenges And Solutions - Proceedings Of The 11th International Business Information Management Association Conference, Ibima 2009 (Pp. 1-8).

Kiseleva, E. M., Nekrasova, M. L., Mayorova, M. A., Rudenko, M. N., \& Kankhva, V. S. (2016). The Theory And Practice Of Customer Loyalty Management And Customer Focus In The Enterprise Activity. International Review Of Management And Marketing.

Kotler, P. (2011). Manajemen Pemasaran Di Indonesia : Analisis, Perencanaan, Implementasi Dan Pengendalian. Jakarta: Salemba Empat.

Kotler, P., \& Keller, K. L. (2016). A Framework For Marketing Management. Marketing Management.

Kurniawan, I., Santoso, S. B., \& Dwiyanto, B. M. (2007). Analisis Faktor-Faktor Yang Mempengaruhi Minat Beli Ulang Produk Serta Dampaknya Terhadap Loyalitas Pelanggan (Studi Kasus Pada Produk Sakatonik Liver Di Kota Semarang). Jurnal Studi Manajemen \& Organisasi, 4(2), 20-29.

Mulyono, B. H. (2007). Analisis Pengaruh Kualitas Produk Dan Kualitas Layanan Terhadap Kepuasan Konsumen (Studi Kasus Pada Perumahan Puri Mediterania Semarang). Jurnal Studi Manajemen \& Organisasi, 4(2), 91100. 
Nurlisa, F. R. S. (2010). Pengaruh Harga, Kualitas Produk, Dan Citra Merek Terhadap Keputusan Pembelian Kecap Manis Merek Bango (Studi Kasus Pada Ibu Rumah Tangga Di Kompleks Villa Mutiara Johor Ii Dan Taman Johor Mas). Jurnal Fe Usu Departemen Manajemen.

Palma, M. A. (2016). Pengaruh Kualitas Produk, Kemudahan, Dan Harga Terhadap Niat Beli Ulang Dengan Kepuasan Sebagai Variabel Intervening (Studi Pada Pelanggan Produk Fashion Melalui Toko Online Di Surabaya). Jurnal Riset Ekonomi Dan Manajemen, 16(1), 84-104.

Parasuraman, A. ; Zeithaml, V. A. ; \& Berry, L. L. (1988). Servqual: A MultipleItem Scale For Measuring Consumer Perc. Journal Of Retailing; Spring.

Pradini, W. (2011). Analisis Pengaruh Kualitas Layanan Dan Brand Image Terhadap Minat Beli Ulang Pada Restoran Kentucky Fried Chicken (Kfc). Jurnal Fakultas Ekonomika Dan Bisnis, Universitas Kristen Satya Wacana.

Pratiwi, Y. R. (2017). Pengaruh Word Of Mouth Communication Terhadap Keputusan Pembelian Konsumen Pada Boardgame Lounge Smart Cafe Pekanbaru. Jom Fisip.

Ramadhan, A., G., Dan Santosa, S., B. (2017). Analisis Pengaruh Kualitas Produk, Kualitas Pelayanan, Dan Citra Merek Terhadap Minat Beli Ulang Pada Sepatu Nike Running Di Semarang Melalui Kepuasan Pelanggan Sebagai Variabel Intervening. Diponegoro Journal Of Management, 6(1), $1-12$.

Ramadhan, A. G., \& Santosa, S. B. (2017). Analisis Pengaruh Kualitas Produk, Kualitas Pelayanan, Dan Citra Merek Terhadap Minat Beli Ulang Pada Sepatu Nike Running Di Semarang Melalui Kepuasan Pelanggan Sebagai Variabel Intervening. Diponegoro Journal Of Management, 6(1), 1-12.

Saidani, B., \& Arifin, S. (2012). Pengaruh Kualitas Produk Dan Kualitas Layanan Terhadap Kepuasan Konsumen Dan Minat Beli Pada Ranch Market. Jurnal Riset Manajemen Sains Indonesia, 3(1), 1-22.

Siburian, P. S., \& Zainurossalamia, S. Z. (2016). Pengaruh Kualitas Produk Dan Kualitas Layanan Terhadap Keputusan Pembelian Sepeda Motor Honda. Kinerja : Jurnal Ekonomi Dan Manajemen.

Suardi, R. (2003). Sistem Manajemen Mutu, Penerapannya Untuk Mencapai Tqm (2nd Ed.). Jakarta: Ppm.

Tjiptono, F. (2008). Pemasaran Strategik. Yogyakarta: Andi. 